\title{
Russian Language Testing and Integrated Examination for Foreign Citizens in Russia: Legislation Background and Legal Regulation Specific Features
}

\author{
Anzhela Dolzhikova ${ }^{1}$ \\ ${ }^{1}$ Peoples' Friendship University of Russia, Russian Federation \\ Correspondence: Anzhela Dolzhikova, Peoples' Friendship University of Russia, Miklukho-Maklaya Str. 6, \\ 117198 Moscow, Russian Federation. E-mail: anzhela.dolzhikova@mail.ru
}

Received: October 28, 2014 Accepted: November 28, 2014 Online Published: February 26, 2015

doi:10.5539/ies.v8n3p193 URL: http://dx.doi.org/10.5539/ies.v8n3p193

\begin{abstract}
The Russian Federation faces active law-making and legislative activities aimed at providing legal grounds for qualifying educational level of foreign nationals entering the country with the purpose to work and apply for citizenship. The article deals with the current legislation and regulations in their relationship with each other, their impact on migration in the Russian Federation, as well as the perspectives of various educational procedures legal regulation development.
\end{abstract}

Keywords: migration, language testing, integration examination, foreign workers, foreign nationals applying for citizenship, adaptation, and integration of foreign nationals

\section{Introduction}

Over the last decades, Russia has become an attractive country for migration. The flow of migrants has increased tenfold. According to the Federal Migration Service of Russia in 2013, 135788 people received Russian citizenship, 350093 received residence permit and temporary residence permit, 1273984 migrants simultaneously perform labour activities (Information, 2013). This put Russia on a par with the major migration-attractive countries and required a serious legal support in various aspects of migrants' life in the Russian Federation. Legal regulation of foreign nationals' educational issues has a number of specific features. Primarily, it is important to specify the main categories of foreign citizens who undertake today lingvodidactic (language) testing in Russian as a foreign language (hereinafter-RFL) (Table 1).

Table 1. Categories of foreign citizens, who undertake language testing in 2014

\begin{tabular}{|c|c|c|}
\hline Foreign Citizens Category & $\begin{array}{l}\text { Legal } \\
\text { Regulation }\end{array}$ & Legal Document \\
\hline \multirow{2}{*}{$\begin{array}{l}\text { 1. Foreign citizens applying } \\
\text { for citizenship, residence } \\
\text { permit temporary residence } \\
\text { permit }\end{array}$} & \multirow[t]{2}{*}{ Yes } & $\begin{array}{l}\text { Federal Law N 115-FZ "On Legal Status of Foreign Citizens } \\
\text { in the Russian Federation", of July 25, } 2002 \text { г. N 115-Ф3 } \\
\text { Presidential Decree N } 1325\end{array}$ \\
\hline & & $\begin{array}{l}\text { "On Approval of the Procedure to Consider the Russian } \\
\text { Federation Citizenship Issues " of November 14, } 2002\end{array}$ \\
\hline $\begin{array}{l}\text { 2. Foreign citizens who arrive } \\
\text { in Russia to work }\end{array}$ & Yes & $\begin{array}{l}\text { Federal Law №185-FZ of } 12 \text { November } 2012 \text { "On Amendments } \\
\text { to Article } 13.1 \text { of the Federal Law" On the Legal Status of } \\
\text { Foreign Citizens in the Russian Federation "and Article } 27.2 \text { of } \\
\text { the RF Law" On Education” }\end{array}$ \\
\hline $\begin{array}{l}\text { 3. Foreign citizens learning } \\
\text { Russian by their own initiative }\end{array}$ & No & $\begin{array}{l}\text { RF Ministry of Education and Science Order № } 463 \text { "On } \\
\text { approval of the federal government requirements for Russian } \\
\text { language as a foreign language” of } 14.12 .2009\end{array}$ \\
\hline
\end{tabular}

As it can be seen from Table 1, testing in Russian as a foreign language is mandatory for two categories of 
foreign citizens under the Russian law. The third category does the test voluntarily for own educational goals, as well as by the initiative of employers. Testing of all categories of foreign citizens is carried out by RFL levels that correspond to the European system of language testing ALTE (The Association of Language Testers of Europe).

This article analyses the legal regulation of testing foreign citizens in compliance with the requirements of the Russian legislation (categories 1 and 2 of Table 1).

For some categories of foreign citizens who undergo the language test, the two new educational procedures are introduced to define the foreign nationals' educational level. The first of the above is the examination in the Russian language, Russian history, and the basics of Russian legislation. Its administration is initiated by the Presidential Decree of May 7, 2012 N 602 "On ensuring inter-ethnic harmony" (Decree, 602). The second procedure includes interviews that result in the recognition or non-recognition of foreign citizens as the Russian language native speaker (Federal Law of April 20, 2014 N 71-FZ "On Amending the Federal Law "On Citizenship of the Russian Federation" and certain legislative acts of the Russian Federation" Federal Law, 71).

Table 2 introduces educational procedures that various categories of foreign citizens have to pass in accordance with the new legislation of the Russian Federation.

Table 2. Classification of foreign citizens and educational procedures under new legislation

\begin{tabular}{|c|c|c|c|}
\hline $\begin{array}{l}\text { Foreign Citizens } \\
\text { Category }\end{array}$ & $\begin{array}{l}\text { Lingvodidactic } \\
\text { Testing }\end{array}$ & $\begin{array}{l}\text { Integral Examination } \\
\text { (starting 01.01.2015) }\end{array}$ & $\begin{array}{l}\text { Interview to recognize or not } \\
\text { recognize a foreign citizen as } \\
\text { Russian language native speaker } \\
\text { (start } 01.05 .2014 \text { ) }\end{array}$ \\
\hline \multicolumn{4}{|l|}{$\begin{array}{l}\text { 1A Foreign citizens applying } \\
\text { for citizenship }\end{array}$} \\
\hline $\begin{array}{l}\text { 1AA Compatriots-Russian } \\
\text { native speakers }\end{array}$ & + & & + \\
\hline $\begin{array}{l}\text { 15 Foreign citizens applying } \\
\text { for temporary residence permit }\end{array}$ & & + & \\
\hline $\begin{array}{l}\text { 1B Foreign citizens applying } \\
\text { for permanent residence in RF }\end{array}$ & & + & \\
\hline 2. Foreign staff & & + & \\
\hline
\end{tabular}

Legal regulation of the above outlined educational procedures has the following particular features.

On December 1, 2012, Federal Law № 185-FZ has found that migrant workers working in the sphere of housing and communal services, retail and consumer services must pass tests in Russian as a foreign language. Thus, the development of requirements for the knowledge of Russian as a foreign language and test materials, in general, and creation of infrastructure for the exam was put on the agenda of the professional community (Federal Law, 185).

April 20, 2014, the Russian President signed Federal Law № 74-FZ, providing integration examination for four categories of foreign nationals. For example, a person wishing to obtain a work permit or a patent, as well as a temporary residence permit and a residence permit must pass this exam, which became another general task for the professional community.

Pursuant to the Federal Law No. 71-FZ of the FMS of Russia approved on May 26, 2014, two orders were issued. The orders are Order No. 379 "On approval of requirements to specialists, members of the Commission for the recognition of a foreign citizen or stateless person as the Russian language native speaker; the rules of the committee's interview with a foreign citizen or a stateless person for the recognition of a foreign citizen or stateless person as the Russian language native speaker; the requirements for the form of application for recognition of a foreign citizen or stateless person as the Russian language native speaker and requirements for the form of the committee's decision on the recognition of a foreign citizen or stateless person as the Russian language native speaker" (Order 379) and the Order No. 380 "On the formation and work of the commissions for the recognition of a foreign citizen or stateless person as the Russian language native speaker" (Order 380). With 
these orders, Russia introduced a unique of its kind procedure for naturalization through the Commission for the recognition.

There is a significant lack of balance resulting from current legal regulation: foreign workers arriving in the country, starting from 01.01.2015 will take the more complex integration examination in the Russian language, Russian history and the basics of the Russian legislation, while individuals applying for citizenship, will have to pass language test or will be interviewed with the purpose to prove their Russian language level as that of native speakers. Thus, the requirements for individuals who are involved in labour activities in the country will be significantly stronger than those for foreign nationals who apply for citizenship.

The above situation might be regarded as flaw in the legislation. However, it is important to underline that the emergence of a visible imbalance between the requirements is caused by attempts to solve various geopolitical issues, namely:

In accordance with Migration Policy Concept of the Russian Federation (Concept, 2012), Compatriots' attraction to Russia and the simplified procedure for them to obtain Russian citizenship should not face obstacles due to too high educational level requirements. The situation is somewhat different with foreign workers.

We can state that our country has been flooded with migrant workers. According to the Federal Migration Service of Russia in 2013, 1.5 million people were legally exercised career in the country (Information, 2014). According to some estimates, 3.6 million people illegally worked in the country (Vzglyad, 2014).

The statistics shows that only the general flow of legal migrant workers, overcomes at least 10 times the flow of individuals applying for citizenship or residence permits in the country. In addition, if we add to this amount those foreign citizens, who work illegally, that proportion will change: the amount of actually migrant workers in the country will be 20-25 times higher than the number of those applying for citizenship.

Migrant workers come at a rate that is dramatically increasing. Due to the above situation, the creation of some barriers to this category of foreign nationals has become a necessity. Today an extremely simplified procedure is still in force for them to confirm their rather low level of proficiency in Russian, close to the elementary one (basic level for migrant workers is 850 lexical units). From 2015, foreign workers will take the exam, which would be suitable for minimal adaptation procedures.

The second feature of legal regulation is that the issues of language test, integration test and an interview with foreign nationals are regulated by various legislative acts, which do not always agree with each other, and on some issues even conflict.

The third feature of legal regulation of educational procedures for foreign nationals is that both statutory acts and a number of obsolete bylaws are functioning at the same time. The above complicates the current enforcement practices during language testing and can be a serious barrier to other educational procedures enactment.

\section{Literature Review}

Although integration tests for migrants raise attention of policy and academia, there is a significant lack in scientific evaluation of the exams (Kiseleva \& Khlgatyan, 2014). Among completed researches, we should mention a project of the Radboud University Nijmegen (Centre for Migration Law) called The INTEC Project 'Integration and Naturalization tests: the new way to European Citizenship. A Comparative study in nine Member States on the national policies concerning integration and naturalization tests and their effects on integration' (INTEC, 2010). The title of the project speaks for itself, nine countries' experience is explored separately and, then, comparatively (Strik, Böcker, Luiten, \& van Oers, 2010). Several latest documents by the Council of Europe are also directly devoted to the problems caused by integration tests (Resolution, 1973; Recommendation, 2034; Strik, 2013). Taken in a wider context, integration procedures for migrants are also studied in frames of different naturalization procedures (Wallace Goodman S., 2010), liberal values of democratic societies (How liberal, 2010), etc. In the Russian Federation the first review paper about civic tests legal aspects was an analytical report by Commersant. Power, published in 2007 (Kachurovskaya \& Kukolevskii, 2007). In 2014, great work in the field of analysing legal regulation of integration tests in various states was done by the team of the Peoples' Friendship University of Russia (Agrba \& Kazhaeva, 2014; Kazhaeva, 2014; Kazhaeva \& Kiseleva, 2014; Kazhaeva \& Khlgatyan, 2014; Kiseleva, 2014; Kiseleva \& Kazhaeva, 2014; Kiseleva \& Khlgatyan, 2014). It should also be noted that practice of integration tests engages, beside mentioned, with wider problems, e.g. role of education in maintaining inter-ethnic concord or international peace (Semenova, 2012, 2013). 


\section{Methods and Data}

This article provides an insider's information on the development of the Russian language testing system.

The data for the present article is derived from the author's experience in elaboration of the legal basis, testing and preparatory materials for introduction of the complex examination for migrants into Russia in Russian as a foreign language, history of Russia and the basics of the Russian legal system. The author is a member of the team of the Peoples' Friendship University of Russia. This University is one of the four members of the Russian Testing Consortium that was at the beginnings of migrants testing in Russia in 2012. The author followed the whole work, from the issuance of the state order for elaboration of scientific and experimental basis for the introduction of the comprehensive examination of migrants up to the present moment. In addition, the author was directly involved into the academia, state officials and civil society meetings, discussions, etc.

The approbation of the test was carried out through more than 50 testing centres in Russia and 10 testing centres abroad, covering more than 500 tested persons. Synthesized results of the approbation were either accessible to the author or made herself. Besides, many wise remarks that became a part of the present article, were given to the author during a number of retraining courses organized at the Russian Testing Consortium Members throughout 2014.

The legal basis for the examination was elaborated with personal participation by this author through multiple meetings with experts, representatives of state, academia, and civil society that were held throughout 2014 , as well as in 2013. Many aspects of the present legal regulation were formulated with the author's contribution, either survived the debates or were amended thereby.

The sources behind the present text are the newest and most up-to-date in the respective field.

\section{Results}

\subsection{Legal Regulation of Educational Procedures for the Admission of Foreign Citizens in the Russian Citizenship (Testing and Interviewing)}

Mandatory testing of foreigners applying for citizenship is carried out in accordance with the Federal Law N 62-FZ "On Citizenship of the Russian Federation" of May 31, 2002 (Federal Law, 62), Presidential Decree N 1325 "On Approval of the Procedure to Consider the Russian Federation Citizenship Issues " of November 14, 2002 (Decree, 1325), Presidential Decree N 964 "On Amendments to the Regulations on the procedure for considering issues of citizenship of the Russian Federation, approved by Presidential Decree of November 14, 2002 № 1325" of December 28, 2013 (Decree, 964). According to the above legislation the person applying for Russian citizenship has to master the Russian language at the basic TORFL level (1300 lexical units), at least.

To develop the above legislation of the Russian Ministry of Education and Science a number of orders regulating the language testing procedure were enacted in 2004-2010:

- Order № 735 of the Ministry of Education and Science of the Russian Federation of 18 February 2004 "On approval of the list of educational institutions to test foreign citizens and stateless persons in the Russian as a foreign language for admission into the Russian Federation citizenship" (Order, 735);

- Order № 463 "On approval of the federal government requirements for Russian language as a foreign language" of October 28, 2009 (Order, 463);

- Order № 207 of 24.03.2010 "On approval of state testing of foreign citizens and stateless persons in the Russian language as a foreign language" (Order, 207);

- Order № 765 of the Ministry of Education and Science of the Russian Federation of July 13, 2010 "On approval of the procedure to award a certificate on passing state testing of foreign citizens in the Russian language as a foreign language, issued by the educational institution (organization) in the territory of the Russian Federation or abroad, licensed by the Ministry of Education and Science of the Russian Federation to conduct such testing" (Order, 765).

It should be singled out that the above orders are outdated and do not meet modern requirements for testing system. Recently the migration situation has undergone significant changes and the conception of migration policy has been approved. The above facts, on the one hand, and the new law N 273-FZ "On education in the Russian Federation" of December 29, 2012 (Federal Law, 273) on the other, have had a significant impact on the configuration of the language testing system in the country.

Over the past years, the language testing system has developed significantly. Four universities have acquired the status of testing system developers (Moscow State University, St. Petersburg State University, Peoples' 
Friendship University, and State Institute of Russian Language named after Pushkin). The above universities have formed the public organization "Russian Language Testing Consortium" that provides organizational and methodological testing system support.

Today more than 250 local testing centres interact methodologically and organizationally with one of the university-testing system developers. The list of the above educational institutions compiled by the Russian Ministry of Education and Science in 2004 (Order, 735) is out of date, it requires updating and cannot meet the current needs of the State in the foreign nationals testing.

Today, the real list of organizations engaged in testing, is posted on the websites of the Russian Ministry of Education and Science and the Russian Language Testing Consortium.

Besides that, a new edition of the Order on the requirements to the level of language proficiency is required, as in the current version TORFL the elementary level is lost; the harmonization of the Orders terminology is required, as well.

It is essential to update an existing certificate form taking into account the possibility and necessity of the electronic bar coding. Moreover, the existing orders of the Russian Ministry of Education and Science have come into conflict with the newly adopted legislation on some issues.

Another important point is related to the fact that current Federal Law in force FZ № 273 "On education in the Russian Federation" (Federal Law, 273) has not vested authorities in the RF Ministry of Education and Science regarding the management and regulation of foreign citizens testing system, in contrast to the old Federal Law of August 22, 1996 N 125-FZ “On Higher and Postgraduate Professional Education” (Federal Law, 125).

The current legal and organizational contradictions required the Presidential Decree vesting the RF Ministry of Education and Science with the necessary powers and a new package of the RF Ministry of Education and Science orders.

The status quo in the normative and legal regulation has a negative impact on the development of the test system in particular and migration processes in the country as a whole. The government pays serious attention to these issues.

Presidential Decree № 964 "On Amendments to the Regulations on the Procedure Concerning Issues of the Russian Federation Citizenship", of 28 December 2013 (Decree, 964), provides as follows:

1) Language testing shall be conducted by the educational institutions;

2) The Ministry of Education and Science of Russia has been empowered to determine the form and procedure of language testing, criteria and procedure for the institutions to be included in the list of testing organizations, and levels of proficiency in Russian, as well as the certificate model form and the technical requirements for the certificate.

The decree defines other documents confirming foreign citizens' level of the Russian language proficiency.

Today, the system of language testing has received new package of orders that established necessary conditions and procedures for testing. In particular, in 2014, the Russian Ministry of Education and Science approved the following orders:

- The Order of 01.04.2014, № 255 "On approval of the levels of Russian as a foreign language, and the requirements for them" (Order, 255);

- The Order of 25.04.2014, № 412 "On approval of the form of the issuance of certificate of passing the state test of Russian as a foreign language and technical requirements to it" (Order, 412);

- The Order of 18.06.2014 № 667 “On Approval of the Procedure of State and test of Russian as a foreign language" (Order, 667).

While analysing the legislation regulating the educational procedures for admission into the citizenship of the Russian Federation, it is necessary to pay attention to Federal Law N 71-FZ "On Amending the Federal Law "On Citizenship of the Russian Federation" of April 20, 2014 and certain legislative acts of the Russian Federation" (Federal Law, 71).

This law introduced the concept of "native speaker of Russian", and envisages setting up the commissions "for the foreign national's recognition as the Russian language native speaker». The RF FMS has drafted the order that establishes the interview rules and specifies the requirements for foreign citizens and members of the committees subject to the existing requirements of the Russian Ministry of Education and Science (Requirements for foreign citizens' proficiency in Russian that are tailored to the existing federal requirements). 
C1 level of Russian as a foreign language has been determined as the criterion to identify the status of the Russian Language native speaker. The above level confirms the high degree of foreign citizen's communicative competence.

However, it is of some concern that such a high and complicated level of Russian language proficiency shall be confirmed by the commission that is headed by the specialist who heads the non-core institution with respect to education, namely the head of the territorial office of the Federal Migration Service of Russia.

\subsection{Legal Regulation of Migrants Testing}

The mandatory testing of certain categories of migrant workers was introduced by Federal Law No. 185-FZ of 12 November 2012 "On Amendments to Article 13.1 of the Federal Law "On the Legal Status of Foreign Citizens in the Russian Federation "and Article 27.2 of the RF Law "On Education" (Federal Law, 185). The above testing has become mandatory since 01.12.2012.

Testing for migrant workers is based on the level of Russian language proficiency that is called the basic one, which, in essence, goes between the basic and elementary traditional levels of TORFL and requires 850 lexical units mastery.

The language testing for migrant workers will be replaced by an integrated examination in the Russian language, history of Russia and the basics of the Russian legislation, starting 01.01.2015. Federal Law of April 20, $2014 \mathrm{~N}$ 74-FZ "On Amending the Federal Law "On the Legal Status of Foreign Citizens in the Russian Federation" (Federal Law, 74) provides the basic organizational principles of such an examination, namely:

- Expansion of categories of foreign citizens who have to undertake such an exam (foreign nationals who receive a temporary residence permit will have to pass the exam, besides all migrant workers including persons applying for a patent);

- Vesting the RF Ministry of Education and Science with powers;

- The examination is conducted only by educational organizations;

- The law provides for the possibility to take the exam from 01.09 .2014 , to ensure a smooth transition from language testing to the integrated examination.

The adopted federal law requires additional regulation by the Russian Ministry of Education and Science.

There is a strong need to adopt a package of orders regulating the procedure to conduct the integrated examination in the Russian Federation.

Four orders are expected to be issued:

- "On Approval of complex requirements to the level of proficiency in Russian and to the scope of knowledge of Russian history and the basics of the Russian Federation legislation, that foreign citizens have to meet while applying for temporary residence permit, residence permit, work permit or patent permit";

- "On the procedure and criteria for educational institutions to be included in the list of educational organizations conducting the examination in Russian language, Russian history and the basics of the Russian Federation legislation" (adopted - Order, 1153);

- "On the model form, technical requirements and procedure of issuing a certificate of the integrated examination in the Russian language, Russian history and the basics of the Russian Federation legislation" (adopted - Order, 1156);

- "On approval of the procedure of conducting the examination in Russian language, Russian history, and the basics of the Russian Federation legislation".

\section{Discussion and Conclusions}

The issue of the above-mentioned orders finalize the creation of the legal and regulatory framework for introducing a comprehensive integrated examination for foreign citizens who undergo educational procedures in accordance with the Russian legislation. Nevertheless, a number of legal issues will remain for further deliberations. Those most obvious are the following:

1) Would the integrated examination be introduced for persons applying for the Russian Federation citizenship?

2) No fee payment issues are released in the draft legal documents regarding integrated examination.

3) No procedure is defined for accounting the results of tests in Russian as a foreign language at levels beyond 
the basic TORFL.

In the final analysis we draw the conclusion that the above regulations and draft documents are necessary but not sufficient for the modern Russian testing system full scale functioning.

To accomplish the legislative agenda in the field under study it is expedient to draft a document that defines the Action Plan for educational training of foreign citizens arriving in Russia, under the working title "The concept of educational policy for foreign citizens arriving in Russia».

"The Regulations on State Testing System of Foreign citizens" should be another important document that will bring all educational procedures for foreign citizens in Russia into a unified logical system and determine the interaction procedure of the State testing system members.

\section{Acknowledgements}

The work was financially supported by the Ministry of Education and Science of the Russian Federation in frames of scientific work in 2014 No. 10.9063.2014.

\section{References}

Agrba, A., \& Kazhaeva, O. (2014). Integration examination for migrants in Spain: legal aspects. Current issues of contemporary international law: XII annual international scientific practical conference commemorating Prof. Igor P. Blischenko. Moscow, April 11-12, 2014 (forthcoming).

Concept. (2012). State Migration Policy Concept of the Russian Federation for the period up to 2025, 19.07.2012. Retrieved from http://www.confidencegroup.ru/news.aspx?sid=71\&id=183\&back-url=/Default. aspx?sid\%3D71\&language $=$ en-US

Decree, 1325. (2002). President of the Russian Federation. On approval of regulation of the order of considering issues of citizenship of the Russian Federation.

Decree, 602. (2012). President of the Russian Federation. On securing inter-ethnic concord.

Decree, 964. (2013). President of the Russian Federation. On amendments to Regulation on the order of deciding the issues of citizenship of the Russian Federation as approved by the Presidential Decree No. 1325.

Federal Law, 125. (1996). On higher and postgraduate professional education.

Federal Law, 185. (2012). On amendments to Art. 131 of the Federal Law On the legal status of foreign citizens in Russia and to Art. 272 of the Law On education.

Federal Law, 273. (2012). On education in the Russian Federation.

Federal Law, 62. (2002). On citizenship of the Russian Federation.

Federal Law, 71. (2014). On amendments to Federal Law On citizenship of the Russian Federation and several other legislative acts of Russia.

Federal Law, 74. (2014). On amendments to Federal Law On the legal status of foreign citizens in Russia.

Goodman, S. W. (2010). Naturalisation Policies in Europe: Exploring Patterns of Inclusion and Exclusion. European University Institute, Florence. Robert Schuman Center for Advanced Studies, EUDO Citizenship Observatory. Retrieved from http://eudo-citizenship.eu/docs/7-Naturalisation\%20Policies\%20in\%20Europe. pdf

How liberal. (2010). Are citizenship tests? In R. Bauboeck, \& C. Joppke (Ed.), European University Insitute Working Paper RSCAS 2010/41.

Information. (2013). On migration situation in the Russian Federation for 12 months of 2013. Federal Migration Service of Russia.

Information. (2014). How many migrants are in Russia. Commersant. Retrieved from http://www.kommersant.ru/doc/2284497

INTEC. (2010). Research program about: Integration and Naturalisation tests. Retrieved from http://www.ru.nl/law/cmr/projects/intec/

Kachurovskaya, A., \& Kukolevskii, A. (2007). Testing with beaver. Retrieved from http://www.kommersant.ru/doc/829223.

Kazhaeva, O. (2014). Structure of the legal module of the integration examination for migrants in Russia. 
Moldavian Journal of International Law and International Relations, 2014(3).

Kazhaeva, O., \& Khlgatyan, A. (2014). Integration examination for migrants in the Czech Republic: Legal aspects. Current issues of contemporary international law: XII annual international scientific practical conference commemorating Prof. Igor P. Blischenko. Moscow, April 11-12, 2014 (forthcoming).

Kazhaeva, O., \& Kiseleva, E. (2014). Integration examination for migrants in the Netherlands: Some legal aspects. Current issues of contemporary international law: XII annual international scientific practical conference commemorating Prof. Igor P. Blischenko. Moscow, April 11-12, 2014 (forthcoming).

Kiseleva, E. (2014). Evolution of structure and substance of the module 'Basics of the Russian legal system' of the integration examination for migrants in Russia. Обозреватель-Observer. 2014. № 12 .

Kiseleva, E., \& Kazhaeva, O. (2014). Legal module of the integration examination for migrants in the light of National and Migration Policies of Russia. Law and legislation, 2014(11).

Kiseleva, E., \& Khlgatyan, A. (2014). Integration test for migrants in Great Britain. Scientific Herald of Uzhgorod National University. Law. 2014. No. 29.

Order, 1153. (2014). Ministry of Education and Science of Russia. On approval of the order of and criteria for inclusion of educational organizations in the list of educational organizations carrying out examination in Russian as a foreign language, history of Russia and basics of the Russian legal system.

Order, 1156. (2014). Ministry of Education and Science of Russia. On approval of the form, order of carrying out examination in Russian as a foreign language, history of Russia and basics of the Russian legal system and approval of requirements to minimal level of knowledge necessary for completion of the stated examination.

Order, 207. (2010). Ministry of Education and Science of Russia. On approval of the order of state testing for foreign nationals in Russian as a foreign language.

Order, 255. (2014). Ministry of Education and Science of Russia. On approval of levels of language mastery in Russian as a foreign language and requirements to them.

Order, 379. (2014). Federal Migration Service of Russia. On approval of requirements towards specialists who are members of the commissions of recognition a foreign national or a stateless person as a native speaker of the Russian language, approval of rules governing interviewing by the commissions of recognition a foreign national or a stateless person as a native speaker of the Russian language, approval of requirements to form of the application for recognition of a foreign national or a stateless person as a native speaker of the Russian language, and approval of requirements to the form of the decision by the commissions of recognition a foreign national or a stateless person as a native speaker of the Russian language.

Order, 380. (2014). Federal Migration Service of Russia. On the order of forming and work of commissions of recognition a foreign national or a stateless person as a native speaker of the Russian language.

Order, 412. (2014). Ministry of Education and Science of Russia. On approval of the form, order of issuing a certificate confirming completion of state testing in Russian as a foreign language and technical specifications to it.

Order, 463. (2009). Ministry of Education and Science of Russia. On approval of federal state requirements for Russian as a foreign language.

Order, 667. (2014). Ministry of Education and Science of Russia. On approval of the form and order of carrying out state testing in Russian as a foreign language.

Order, 735. (2004). Ministry of Education and Science of Russia. On approval of the list of educational organizations (institutions) carrying out state testing in Russian as a foreign language for foreign nationals and stateless persons for naturalization in Russia.

Order, 765. (2010). Ministry of Education and Science of Russia. On approval of the order of issuing a certificate confirming completion of state testing for foreign nationals in Russian as a foreign language, that is issued by the educational institution (organization) in the territory of the Russian Federation or abroad, which is entitled by the Ministry of Education and Science of Russia to carry out such testing.

Recommendation (2034) of the Parliamentary Assembly of the Council of Europe 2034. (2014). Integration tests: Helping or hindering integration?

Resolution (1973) of the Parliamentary Assembly of the Council of Europe 1973. (2014). Integration tests: 


\section{Helping or hindering integration?}

Semenova, N. (2012). Education as a factor of maintaining peace in multi-ethnic society: International legal aspect. Herald of the Gumilev Eurasian National University. Legal Sciences, 1(11), 128-134.

Semenova, N. (2013). Role of human rights education in prevention of inter-ethnic conflicts. Current problems of harmonizing inter-ethnic relations at the municipal level: Proceedings of the scientific practical conference (pp. 162-169). Moscow: Lawer.

Strik, T. (2013). Integration tests: Helping or hindering integration? Committee on Migration, Refugees and Displaced Persons, Netherlands. Retrieved from http://www.assembly.coe.int/nw/xml/XRef/X2H-XrefViewPDF.asp?FileID=19772\&lang=en

Strik, T., Böcker, A., Luiten, M., \& van Oers, R. (2010). Integration and Naturalisation tests: the new way to European Citizenship. A Comparative study in nine Member States on the national policies concerning integration and naturalisation tests and their effects on integration. The INTEC Project: Synthesis Report. Radboud University Nijmegen. Centre for Migration Law. December 2010.

Vzglyad. (2014). Federal Migration Service of Russia: In Russia 3.6 million migrants live illegally. Retrieved from http://www.vz.ru/news/2014/2/26/674557.html

\section{Copyrights}

Copyright for this article is retained by the author(s), with first publication rights granted to the journal.

This is an open-access article distributed under the terms and conditions of the Creative Commons Attribution license (http://creativecommons.org/licenses/by/3.0/). 